\title{
Prioritizing Multilingualism in U.S. Schools: States' Policy Journeys to Enact the Seal of Biliteracy
}

Amy J. Heineke

Loyola University Chicago, aheineke@luc.edu

Kristin J. Davin

University of North Carolina at Charlotte

Follow this and additional works at: https://ecommons.luc.edu/education_facpubs

Part of the Bilingual, Multilingual, and Multicultural Education Commons

\section{Author Manuscript}

This is a pre-publication author manuscript of the final, published article.

\section{Recommended Citation}

Heineke, Amy J. and Davin, Kristin J.. Prioritizing Multilingualism in U.S. Schools: States' Policy Journeys to Enact the Seal of Biliteracy. Educationl Policy, , : 25, 2018. Retrieved from Loyola eCommons, Education: School of Education Faculty Publications and Other Works, http://dx.doi.org/10.1177/ 0895904818802099

This Article is brought to you for free and open access by the Faculty Publications and Other Works by Department at Loyola eCommons. It has been accepted for inclusion in Education: School of Education Faculty Publications and Other Works by an authorized administrator of Loyola eCommons. For more information, please contact ecommons@luc.edu.

\section{(c) $($ () $\ominus$}

This work is licensed under a Creative Commons Attribution-Noncommercial-No Derivative Works 3.0 License. (C) The Authors 2018 
Running Head: SEAL OF BILITERACY

Prioritizing Multilingualism in U.S. Schools: States' Policy Journeys to Enact the Seal of Biliteracy 


\begin{abstract}
Fueled by immigration and globalization, the United States has evolved into a nation of linguistically diverse residents; however, English remains the dominant language in schools. A recent language policy initiative emergent in states across the nation, the Seal of Biliteracy, challenges English monolingualism by promoting the development of students' bilingualism and biliteracy by high school graduation. Using narrative inquiry, this study explores the policy journeys that states have taken to enact the Seal of Biliteracy, as educators and stakeholders come together to engage in grassroots policy work. Findings include the collective stories of these efforts to disrupt English-dominant ideologies in schools, as well as individual states' journeys to develop students' bilingualism. Implications serve educators, researchers, and other stakeholders interested in influencing practice through bottom-up policy movements, particularly at this crucial moment as states embrace more flexibility for educational decision-making.

Key words: bilingual education, biliteracy, educational policy, language policy, world language education
\end{abstract}




\section{Prioritizing Multilingualism in U.S. Schools: States' Policy Journeys to Enact the Seal of Biliteracy}

The ever-changing face of the United States includes a vast array of languages and individuals from diverse linguistic backgrounds. One in five U.S. residents speaks a language other than English, with at least 350 languages represented including 150 languages indigenous to North America (e.g., Navajo, Dakota, 'Ōlelo Hawai'i) and 200 languages brought by immigrants (e.g., Spanish, Arabic, Vietnamese; U.S. Census, 2015). These numbers are mirrored in Kindergarten-through-twelfth-grade (K-12) schools, where approximately $20 \%$ of public school students speak a language other than English with a wide variety of home languages (Digest of Education Statistics, 2015). These linguistically diverse students warrant recognition for their rich language backgrounds and abilities, as well as acknowledgement of how they enhance communities and schools across the country. It is within these diversifying contexts that we see languages as central to participating in daily life: connecting with friends and families, engaging in tasks in diverse schools and communities, and taking part in the larger global economy (Dawson \& Sandrock, 2017). This landscape prompts the need for individuals who are bilingual and biliterate; that is, who are proficient in two or more languages spanning the domains of listening, speaking, reading, and writing.

Whereas bilingualism refers to speaking and listening in two languages, biliteracy goes beyond to include proficiencies in reading and writing (Hornberger, 2003). In this way, biliteracy is considered to be an advanced state of bilingualism ( $\mathrm{Ng}, 2015)$. The benefits of bilingualism and biliteracy span social, cognitive, linguistic, and academic dimensions of individuals' learning and development. From a cognitive standpoint, proficiency in two languages has been linked to enhanced executive functioning that may result in the delayed onset of dementia (Bialystok, 
2007; Bialystok, Craik, \& Freedman, 2007). Additional benefits have been demonstrated by individuals' increased use and overall awareness of multiple languages (McLeay, 2003), as well as greater intercultural awareness and open-mindedness (Byram, 1997). Because of these needs and benefits, multilingualism is the norm across the globe, including Africa, Asia, and Europe (Bhatia \& Ritchie, 2013; Commission of European Communities, 2003; Zsiga, Boyer, \& Kramer, 2014), while formal policies in the United States have historically perpetuated monolingualism (Crawford, 2000).

Various efforts in K-12 schools attempt to push back against monolingual ideologies through educational policies and resultant programs in practice (Lee \& Wright, 2017). Bilingual education involves primarily elementary school students learning in two languages. These programs align to federal requirements and are often subtractive in nature, meaning they only use students' home languages initially as a means to promote learning and proficiency in English (Cummins, 2000; Zelasko \& Antuñez, 2000). Additive bilingual education that aims to develop and maintain students' bilingualism and biliteracy is growing in popularity but still varies by local context, with programs available in about $2 \%$ of U.S. schools (Gross, 2016). World language education involves primarily secondary students learning another language in a single class period. No federal policy related to bilingual or world language education exists and requirements vary by state, resulting in various outcomes in students' language proficiency (Wiley \& García, 2016). These disparate efforts in local municipalities and schools have resulted in scant bilingualism and biliteracy for English-dominant Americans, with only 10\% considered to be highly proficient in languages other than English (Smith, Marsden, \& Hout, 2006). 
Emerging in the past decade, the Seal of Biliteracy movement merges the fields of bilingual and world language education, expanding bilingual education into secondary settings to promote students' proficiency in multiple languages by high school graduation. Different from other policy efforts that typify the top-down nature of American educational reforms, 31 states and the District of Columbia (D.C.) have engaged in grassroots efforts to enact the Seal of Biliteracy, each embarking upon their own journeys to develop policy that matches the unique contexts and needs of particular jurisdictions. In this paper, we explore how the Seal of Biliteracy movement has unfolded across various states. After providing context and literature on the Seal of Biliteracy, we detail our conceptual frameworks to make meaning of this language policy as implemented in contexts across the country. We then explain our methodology, followed by findings that employ narrative inquiry to probe policy efforts to enact the Seal of Biliteracy. We close with a discussion of policy and practice to promote biliteracy across the United States.

\section{Background and Literature Review}

The Seal of Biliteracy as "an award made by a state department of education or local district to recognize a student who has attained proficiency in English and one or more other world languages by high school graduation" (American Council on the Teaching of Foreign Languages, National Association for Bilingual Education, National Council of State Supervisors for Languages, \& Teachers of English to Speakers of Other Languages International Association, 2015, p. 2). In this way, students who demonstrate proficiency in two languages, typically specified as English and one other language, are eligible to earn this distinction that is formally affixed to high school diplomas and transcripts. The underlying premise of the Seal of Biliteracy is that its achievement indicates that a student has a certain level of language proficiency in 
listening, speaking, reading, and writing in two or more languages, which then serves as a "statement of accomplishment for future employers and for college admissions" (Seal of Biliteracy, 2016, p. 2).

While the Seal of Biliteracy itself provides an appealing construct and fruitful idea to promote language education in K-12 schools, it is important to understand the grassroots nature of this language policy. The initiative began in California in 2008, where advocates designed the Seal of Biliteracy to push back against a decade of English-dominant policies guiding practices in schools after the passage of Proposition 227 in 1998, which severely limited opportunities for bilingual education. Following California's legislative efforts in 2011, other states across the nation adopted similar policies. See Figure 1 for states that have successfully passed policy, organized based on the date that the legislation or code passed in each calendar year. The continued expansion of this policy initiative is supported in part by external organizations focused on language education, including the American Council on the Teaching of Foreign Languages (ACTFL), the National Association of Bilingual Education (NABE), Teachers of English to Speakers of Other Languages (TESOL), and the National Council of State Supervisors for Languages (NCSSFL), who widely communicate details regarding ongoing work across states (Authors, 2017).

[Insert Figure 1 around here.]

Despite its wide use in contexts across the nation, this nascent initiative has not been researched extensively, particularly outside of the state of California. Castro-Santana (2014) explored the local enactment of the Seal of Biliteracy in Los Angeles Unified through interviews with students and staff, discerning that the award recognized students' assets, as well as the contributions of parents and community members in promoting home language development and 
maintenance. DeLeon (2014) conducted a mixed-methods dissertation study on the early implementation of the Seal across California districts, finding the individual and collective promotion of biliteracy environments and assessments, but the privileging of elite bilingualism for English-dominant students. Authors (2018) conducted case studies of three Illinois high schools and found that administrators and teachers grappled with how to expand access to the Seal of Biliteracy to more students, particularly those who spoke less commonly taught languages at home. Seeking a lens outside of K-12 settings, Callahan and Gándara (2014) surveyed California universities and businesses and found that most had no prior knowledge of the Seal, but that $66 \%$ reported a preference for bilingual employees.

In a previous article, we reported on the variation that exists in Seal of Biliteracy policy across the country. We found that various requirements exist to earn this award depending on the context, including ways to demonstrate bilingualism. Proficiency in the non-English language is determined through varied means, from taking standardized language proficiency exams, creating portfolios or other performance assessments, or enrolling in world language classes for a set number of years with a minimum grade-point average (GPA). Options to demonstrate English proficiency also vary greatly, such as passing standardized English language arts tests, meeting particular graduation or GPA requirements for English language arts courses, or achieving a particular score on standardized tests of language acquisition (e.g., ACCESS). Further, states offer varying tiers of the award based on different levels of proficiency in the non-English language. While most have only one, some states offer multiple levels of the award (e.g., silver, gold, platinum) based on minimum pre-determined levels of proficiency (i.e., intermediate, advanced). These cross-context nuances enhance the complexity of understanding the Seal of 
Biliteracy as a language policy and influence the number of individuals in each state that earn the award (Authors, 2017).

In the present study, we sought to understand the journeys that states took to pass Seal of Biliteracy policy, to shed light on the actors involved and how unique contexts resulted in such variation. To our knowledge, few studies explore the enactment and implementation of the Seal of Biliteracy outside of California (Authors, 2018; Burnet, 2017). This study seeks to widen this emerging field of research on the Seal of Biliteracy by exploring the initial policy efforts with a macro-level lens spanning states.

\section{Conceptual Framework}

We conceptualize the Seal of Biliteracy as a language education policy, or the formal regulations and informal expectations that attempt to manage and influence language use in classrooms (Spolsky, 2007). Unlike traditional research approaches that probe the static discourse of formal policy documents, we understand policy as socially and culturally situated in local contexts (Levinson \& Sutton, 2001; Rogoff, 2003). This social lens emphasizes the multilayered nature of educational policy, including the various actors involved in policy work, ranging from teachers in classrooms to lawmakers in state and federal government (Author, 2016; Mehta, 2013). But it is not only lawmakers who design policies and teachers who implement policies, but intermediary actors in between like school, district, and state administrators who also interpret, enact, and influence policy in practice (Ricento \& Hornberger, 1996). In this way, policy is not linear and top-down in nature, but dynamic and complex as it moves across layers and actors (McCarty, 2011). The cultural lens recognizes the inherent complexity of educational policy when implemented in unique contexts, underscoring the 
various ways that policy manifests in practice depending on local variables (Hornberger \& Johnson, 2007; Menken \& García, 2010).

We used a three-facet scheme to study educational policy in practice, including the complex and dynamic interactions between policies, people, and places (Honig, 2006; see Figure 2). The first facet, policies, encompasses the goals, processes, targets, and tools and focuses on the demands that specific policies place on stakeholders. The second facet, people, considers the background and experiences of participants involved in policy work, spanning different stakeholders and organizations like legislators, administrators, and teachers. The third facet, places, prioritizes the contexts that shape what people do with policy. This conceptual framework supports the uncovering of the multiple dimensions of policy and "how and why interactions among these dimensions shape implementation in particular ways" (Honig, 2006, p. 14). In this way, the aim is not to seek universal truths about policy design and implementation, but rather to uncover and unfold the unique, complex, and dynamic stories of policies, people, and places interacting to influence students' learning and development in educational practice.

[Insert Figure 2 around here.]

In this paper, we term these multifaceted, storied experiences as policy journeys, capturing and probing the complexity and dynamism of policy-related plots and settings using narrative inquiry (Clandinin \& Connelly, 2000; Connelly \& Clandinin, 1990). Seeking to initiate a broad field of research on these important language education policy efforts, we investigated policy journeys to enact the Seal of Biliteracy (Honig, 2006; Levinson \& Sutton, 2001). In this article, we share our findings in response to the following research questions: What paths have states taken to enact the Seal of Biliteracy? Whose voices and choices guide these policy journeys? How do these policy journeys vary by context? 


\section{Methods}

Part of larger exploratory research on the Seal of Biliteracy, we approached this study with narrative inquiry using qualitative methods (Clandinin \& Connelly, 2000; Erickson, 1986). Qualitative methods allow researchers to capture the unique and complex nuances of layers and actors doing policy work within and across diverse locales (McCarty, 2011; Menken \& García, 2010). Narrative inquiry further supported our investigation into the nuanced educational experiences in various locales across the United States, including those related to the enactment of language policy in practice. The heart of narrative research, we recognize that educational actors actively engage with policy as a part of their storied lives, as embedded in unique settings with varied characters (Connelly \& Clandinin, 1990).

Aligned to the study's purpose to explore the nuanced journeys to enact the Seal of Biliteracy in contexts across the United States, we sought the perspectives of state-level stakeholders to glean their experiences and other related information on the Seal of Biliteracy. Using the assistance of the Seal of Biliteracy organization website and personnel, we gathered contact information and subsequently reached out to stakeholders in the 23 states and D.C. that had passed Seal of Biliteracy policy at the time of the data collection in the fall of 2016. Nineteen individuals agreed to participate, representing 18 states and D.C. Fourteen of these 19 individuals worked at their respective state departments of education. In the remaining five contexts, state administrators referred us to other individuals who coordinated the Seal of Biliteracy efforts, including three individuals within local school districts, one university professor, and one leader in a state-level language education organization.

Data collection centered on interviews with participants, in addition to documentation data that supplemented and supported our narrative inquiry (Connelly \& Clandinin, 1990; 
Seidman, 2005). We conducted virtual interviews with stakeholders (Oppendaker, 2006), posing open-ended questions regarding the processes for instituting the Seal, approaches to publicizing and advocating, considerations regarding stakeholder support and opposition, and details related to schools and students involved. These virtual interviews allowed participants the flexibility to construct stories using their preferred medium, either orally (in a scheduled call with researchers) or in print (using researcher-provided prompts to respond via email). This approach also resulted in varied story lengths, considering some participants had only recently begun their policy journeys in contrast to others more deeply entrenched in the work. In addition to interviews, documentation data from state government and department of education websites, as well as recent census data focused on language use (U.S. Census, 2015), allowed us to further construct the stories of states' Seal of Biliteracy policy efforts.

Data analyses included both inductive (Erickson, 1986) and narrative approaches (Clandinin \& Connelly, 2000) to make meaning of the interviews and documentation with regard to the research questions. The first phase of analysis employed N-Vivo qualitative research software to support the researchers in coding, crafting assertions, and triangulating results (Erickson, 1986). We designed and utilized a coding scheme using the conceptual framework with categories, codes, and sub-codes focused on the policies, people, and places involved in the enactment of the Seal of Biliteracy (Honig, 2006; see Table 1). The second phase of analysis involved crafting the shared stories into holistic narratives of policy work, referred to throughout the article as policy journeys (Clandinin \& Connelly, 2000). In addition to telling the larger story of policy enactment spanning contexts across the country, we fleshed out individual stories that exemplified findings from the inductive analyses in the first phase (Connelly \& Clandinin, 1990; 
Seidman, 2005). We sent participants the resultant narratives to member-check our findings, which are the focus of the next section.

[Insert Table 1 around here.]

\section{Findings}

In this section, we share the findings from our narrative inquiry by constructing and presenting the collective and individual stories detailing the policy journeys to enact the Seal of Biliteracy. We organize the findings into three sub-sections, each prioritizing one research question. In the first sub-section, we explore the paths that states have taken to enact the Seal of Biliteracy, including the initiation, design, and implementation, as well as any opposition faced during the journey. In the second sub-section, we consider how various stakeholders' voices and choices shaped the policy journeys, including the individuals and organizations involved in the unfolding policy work. In the third sub-section, we investigate how these policy journeys varied by context, considering how jurisdiction and linguistic diversity influenced state-by-state experiences enacting the Seal of Biliteracy. Each sub-section includes examples from two states to illustrate the variation in journeys.

\section{Policy Pathways to the Seal of Biliteracy}

The story of the Seal of Biliteracy commenced in 2008 in the state of California - the trailblazer in initiating, designing, and implementing the language policy. Aiming to counteract the monolingual policy that guided K-12 classroom practice with English learners (ELs) at the time, California stakeholders involved with the organization Californians Together enacted the policy to stimulate students' bilingualism and biliteracy. Word of these efforts spread across the nation through national organizations and groups, such as ACTFL and NABE, which provided the impetus for other states to follow their lead and introduce legislation. In each state, a group of 
individuals came together with the goal to foster students' biliteracy and found interested lawmakers to sponsor the bill within state government. Despite wishing to enact a similar language policy, states varied in their goals and targets. Whereas most contexts aimed to promote bilingualism for all students, specifically prioritizing world language study, others set sights on heritage language maintenance targeting ELs and students from linguistically diverse backgrounds, including California, D.C., Hawai ${ }^{`} i$, Minnesota, and Wisconsin.

Each state engaged in one of three pathways to enact the Seal of Biliteracy: (a) legislation that passed through state legislature and the governor, (b) policy resolution that passed through the state board of education, or (c) policy approved by the state department of education. Most states followed the first path with formal legislation, resulting in formal state laws after thorough and iterative review from various stakeholders. The second path through the state board of education, enacted by four states in our study (i.e., Hawaii, Kansas, North Carolina, Oregon), provided a more straightforward route due to the circumvention of state legislature; however, the resultant educational code did not formally attach to legislation. The third path, exemplified by Wisconsin and D.C. in our study, resulted in a policy handbook without formal legislation or educational code. With 13 of 19 contexts in our study taking the first path, policy journeys took approximately three years on average to initiate, pass, pilot, and implement the policy in practice.

States' policy journeys toward the Seal of Biliteracy progressed smoothly with little to no opposition. Some states reported no opposition to the policy, even in right-leaning states that might be viewed as more resistant to policies aligned with multilingual ideologies, such as Georgia, Kansas, and North Carolina. Stakeholders attributed the absence of opposition to the voluntary nature of the policy for schools and districts, as well as the lack of funding required from state budgets. But these states also framed the policy in terms of bilingualism for all 
learners, a construct in line with mainstream ideologies, unlike heritage language maintenance for children from immigrant families. For states reporting some resistance throughout their journeys, opposition connected to lack of understanding, which dissipated following the detailed design and communication of information regarding implementation, such as funding and testing requirements. In more left-leaning states like Hawai' $i$ and Washington, opposition connected to advocacy, as stakeholders reported concerns for particular sub-groups of students, such as the inclusion of heritage languages and involvement of ELs.

Following policy passage, states' journeys shifted to designing policy in preparation for implementation, particularly fleshing out practical details beyond the legislation or code. In contexts across the United States, stakeholders sought multiple perspectives to elaborate the fine points of the language policy, such as looking to other states as models and seeking additional feedback from external actors regarding award levels, proficiency requirements, and available assessments. Some states opted to pilot the Seal of Biliteracy, which involved one or more local school districts laying the groundwork for policy design and implementation by testing procedures, tools, and approaches to evaluate students' biliteracy. Pilots served different purposes in policy journeys, either informing policy design prior to legislation (i.e., New Jersey, Oregon, Rhode Island) or bringing the policy to scale following legislation (i.e., New York, Washington). Once stakeholders finalized details through these varied mediums and collaborations, states shifted course to focus on implementation. This phase of states' policy journeys involved ample work in developing partnerships at the local level, as districts had to voluntarily sign-on to Seal of Biliteracy efforts. State leaders formed relationships and forged partnerships with local educators, often traveling the state to enlist participation through presentations at district offices and state language conferences. 
States varied in their pathways to the Seal of Biliteracy, particularly shaped by the individuals or groups who initiated policy efforts. To explore the nuances across states, we provide examples from two states below: Georgia, whose journey began at the state department of education, and New Jersey, where local language educators organized and advocated for the policy.

\section{Georgia}

The $21^{\text {st }}$ state to pass Seal of Biliteracy legislation, Georgia's journey began in 2014 when administrators in the state department of education drafted an "internal proposal... after gathering ideas and development processes for the Seal" from other states. When the legislative session began in 2015 , a lobbyist reached out to these administrators with interest in putting forth Seal legislation, eventually connecting leadership of the state department with a state legislator who sponsored the bill. After passing almost unanimously in the House, the bill initially struggled in the Senate due to its attachment to an "unpopular bill" that provided opt-out provisions for mandatory standardized testing. After detaching the two pieces of legislation, the Seal of Biliteracy bill subsequently passed with few dissenting votes.

Administrators were pleased with the easy passage of the bill, with one state-level educational leader describing how the process "caught everyone by surprise." The shock stemmed from the situation in a conservative, southern state, where legislators had recently passed a number of bills that prioritized English, such as needing to demonstrate proficiency in English to receive a driver's license (i.e., SB 67). Nonetheless, policy authors did not frame the bill to target the bilingualism of the $13 \%$ of the state's population who speak 125 languages other than English (U.S. Census, 2015), but instead to "encourage pupils to study foreign language" and "promote foreign language instruction in public schools" (HB 879, 2016, p. 1). With the 
assumed focus on developing the bilingualism of English-dominant students, paired with the bill not being tied to any state-level funding, the Seal of Biliteracy sailed through the General Assembly, and the governor signed the bill into law in 2016.

The legislation itself included parameters for implementation in local contexts, including the minimum language proficiency level and specified evaluation measures. Whereas state administrators had initially drafted the policy to include a tiered system, in which students at varying levels of language proficiency would receive different tiers of the Seal of Biliteracy, state legislators reduced the award to one level. The Georgia educational leader reflected, "Something really important [in policy discussions] was to make sure that it is a meaningful Seal. Our business partners really reiterated that the requirements were rigorous so that a certain proficiency level was established." Influenced by feedback from external stakeholders, the legislation aimed to maintain high expectations and provide clear indications of language proficiency for both employers and higher education. Since its passage, the department of education coordinates statewide implementation via communication with local districts and schools, including posting information online, sending emails to superintendents and principals, and presenting at conferences.

\section{New Jersey}

New Jersey’s policy journey began through “grassroots efforts by two professional organizations: FLENJ (foreign language teachers) and NJTESOL/NJBE (ESL bilingual teachers)." Spearheaded by leaders of these organizations, the groups organized a pilot of the Seal of Biliteracy by inviting districts "recognized as model programs in world languages or ESL and bilingual education." After starting with six districts in 2013, they expanded to 25 districts in the final year of their pilot in 2016, including a cross-section of the state with both urban and 
suburban areas in an attempt "to address different types of languages and pathways, [including] IB/AP classes, heritage language Saturday schools, bilingual programs, American Sign Language, Latin, and heritage languages like Swahili and Cebuano." Through this collaborative pilot between professional organizations and diverse school districts, educators developed policy criteria that aligned to the unique context of New Jersey, a state where $30 \%$ of residents speak a language other than English (U.S. Census, 2015). With 128 languages spoken by residents and various language programs enacted in both schools and communities, teachers worked to develop the Seal of Biliteracy with the goal of reaching diverse students across the state.

In the midst of the pilot program, leaders of professional organizations took findings and feedback from local districts to seek macro-level support. The leader of one of the state professional organizations explained,

After the first year [of the pilot program], we contacted an assemblyman on the education committee and asked him to sponsor a bill, which he did and it passed the assembly easily. Then we engaged Partnership for a New American Economy and they helped us get sponsorship in the Senate, where it also passed with little opposition. Last January our governor signed the legislation and now our NJDOE [New Jersey Department of Education] is implementing the Seal.

By enlisting stakeholders in state government, as well as a public advocacy group comprised of mid-Atlantic regional business leaders and mayors, educators successfully secured macro-level support for Seal of Biliteracy legislation. The governor signed the bill into law in 2016, making New Jersey the $17^{\text {th }}$ state to offer the Seal of Biliteracy to public high school students. State administrators took charge of the statewide implementation efforts, including recruiting and communicating with local districts offering the award across the state. The two professional 
organizations also remain closely involved with the ongoing policy efforts, as they advertise and share information with educators online and at conferences in New Jersey.

\section{Stakeholder Voices and Choices}

As portrayed in states' collective and individual stories, policy journeys began with interested citizens that initiated broader discussions to push forward legislation or code related to the Seal of Biliteracy, rather than policies enforced from the top-down by state or federal government actors. Depending on the state, different stakeholders initiated the policy journeys, including (a) administrators in state departments of education (e.g., Georgia), (b) local language educators and advocates collaborating through state-level organizations for language education (e.g., New Jersey), and (c) parents and members of the immigrant community (e.g., Illinois). In addition to those who initiated the work in each state, a broad array of stakeholders influenced the eventual policy or code, including individuals, organizations, associations, and advocacy groups with interests varying from language, culture, education, government, and business. States also employed mechanisms both in-person (i.e., focus groups, pilot programs) and online (i.e., public comment periods, Capwiz online advocacy platform) to invite feedback and extend influence of other citizens and groups not involved in initial policy discussions.

The ongoing policy work typically centered on state administrators with support and involvement of local administrators and educators. These partnerships took two forms: (a) states collaborated with local stakeholders to flesh out details of the award prior to implementation, or (b) states enlisted local educators with predetermined procedures to implement in schools and districts. In the former category, state administrators worked with local educators and community stakeholders to determine details such as levels of the award, language proficiency requirements, and types of assessments. In the latter group, details were typically predetermined through 
preliminary pilots, legislative processes, or both, leaving the implementation work centered on enlisting districts to participate. Across contexts, these partnerships between states and districts remained integral as stakeholders sought to expand the Seal of Biliteracy to multiple schools across the state, relying primarily on the point people in state administration charged with coordinating and communicating the policy. Because of their grassroots nature, all policy journeys unfolded without any funding to motivate or subsidize efforts. In this way, people became the all-important medium to push forward the work, requiring collaboration and communication across stakeholders to implement the policy in practice.

Whereas states shared similarities in the diverse voices and choices that influenced the evolution of the policy work, one clear distinction emerged: those policy journeys that included or excluded university stakeholders. The majority of states did not involve universities and looked to other stakeholders for guidance. In Georgia, state leaders shaped legislation around feedback from those in commerce and industry. In other states like Kansas and New Jersey, the incorporation of K-12 teachers and language education organizations provided the needed expertise that may have otherwise been sought from university-based educators. But other states found various ways for universities to participate in efforts around the Seal of Biliteracy. In Minnesota and Illinois, stakeholders recognized the importance of universities when writing the legislation, and the award became associated with college credit. In Hawai' $i$, the partnership between the state department and public university became integral during implementation, as they worked together to design assessments for less-commonly taught languages and pathways for students to utilize credit in college courses. To capture the engagement of diverse educational stakeholders during both policy design and implementation, we provide examples from two states-Minnesota and Illinois. 


\section{Minnesota}

A unique array of people initiated policy efforts in Minnesota, where "all the stars aligned" to result in the passage of legislation enacting Minnesota's Bilingual and Multilingual Seals in 2014, making Minnesota the $8^{\text {th }}$ state to offer the award. Members of the Spanishspeaking community had learned of the Seal of Biliteracy in California and approached a Minnesota state representative in hopes of passing similar legislation. Simultaneously, a Chinese-American high school student advocated to his state representative after earning a world language proficiency certificate that he considered insufficient to address his level of proficiency in Chinese. Simultaneously, lawmakers, educators, and community groups grappled to address the achievement gap and dropout rate of ELs. This ultimately resulted in the Learning English for Academic Proficiency and Success (LEAPS) Act, which included the enactment of both a Bilingual Seal and Multilingual Seal, with a focus on ELs from all language backgrounds in public and non-public schools.

The discourse of the legislation prompted the involvement of two groups beyond state employees: language and education experts from ACTFL and universities. First, the legislation explicitly made the Seal available to speakers of all languages. In this Midwestern state where 11\% of residents speak one of 129 languages other than English, including large populations of speakers of less commonly taught languages such as Hmong and Somali (U.S. Census, 2015) ${ }^{1}$, state administrators partnered with ACTFL to develop assessments in multiple languages for which no proficiency assessments were previously available. Second, the legislation required Minnesota State colleges to grant college credit for high school graduates receiving this award, while leaving flexibility for implementation at the University of Minnesota. The revised policy

\footnotetext{
${ }^{1}$ Data from the Minnesota Department of Education differs substantially from the U.S. Census. The state-level participant in this study reported 435 languages other than English spoken by students.
} 
statute states: "The University of Minnesota is encouraged [emphasis added] to award students' foreign language academic credits" (Statute 120B.022, 2017). Nonetheless, the state administrator and world language expert shared that the state's flagship university "is not granting semester credits and, to our knowledge, is not discussing whether or not to grant credits" for the state's Bilingual Seal.

\section{Illinois}

With 138 languages spoken by $22 \%$ of state residents (U.S. Census, 2015), the Midwestern state of Illinois became the $4^{\text {th }}$ state to pass Seal of Biliteracy legislation in 2013, following years of dialogue and advocacy work across stakeholders. The efforts began as a grassroots initiative connected to the work of Multilingual Chicago, a coalition of individuals and organizations with the mission "to recognize and promote the many languages spoken in our city [Chicago]" (Multilingual Chicago, 2017). The coalition brought the Seal of Biliteracy to the attention of three Latina state legislators, who sponsored the bill that passed unanimously through the Senate and House. The department of education, specifically the division in charge of bilingual education, then brought together stakeholders to draft the rules and specific design of the language policy. A state administrator recounted,

There was a meeting of stakeholders, both from the WL [world language] community and the EL [English learner] community... They also had a strong presence from districts with bilingual programs, as well as university representatives. There was a meeting of that group before the rules were written and finalized.

In addition to including perspectives from world language, bilingual, and ESL education, state administrators engaged university professors in these discussions alongside district leaders, 
building on long-standing partnerships from other state-level initiatives, such as writing ESL and bilingual teacher preparation standards.

These conversations involving multiple voices continued at the local level when two districts first implemented the Seal of Biliteracy, including one large, urban district with $660 \mathrm{~K}-$ 12 schools and one small, suburban district with three high schools. The Chicago Public Schools convened a group of stakeholders to shape policy implementation, including principals with high-performing bilingual and world language programs, district leaders in world language, bilingual, and ESL education, and university professors who prepare language teachers and work regularly with schools. The experiences of implementing the policy locally then returned to inform state-level work, as administrators convened "a focus group of districts that had participated to discuss their experiences and use that to inform the program for the following year." The department of education has expanded outreach efforts in recent years, including a one-time symposium and regular "Seal of Biliteracy newsletter" for district leaders, conference presentations for educators, and bilingual parent summits for students and families.

\section{Policy Journeys across Contexts}

Just as different people influenced the Seal of Biliteracy work in various ways across the nation, the unique contexts of states shaped the resultant journeys to enact language policy in practice. For example, states' policy journeys differed in the number and types of districts involved, ranging from one (i.e., Hawai'i) to 61 (i.e, California). Unlike Hawai'i, which only has one school district and required participation of all public, non-charter high schools, other states left participation voluntary to local districts across their wider jurisdictions. In states like Oregon and New Jersey, stakeholders strategically planned recruitment efforts to engage districts from urban, suburban, and rural settings across the state. Other states' journeys centered on smaller 
numbers of districts in focused locations, like the two participating districts in Wisconsin situated in suburbs of Madison and Milwaukee. Whereas other initiatives across the country started at the state level and spanned out to involve districts, D.C. enacted the Seal at the district level.

States varied with regard to the types of educational settings involved in implementing the Seal of Biliteracy, either excluding or including private schools. Most states fell into the former category, as state departments of public education maintained purview over the award. Despite this limitation, some states sought to extend the Seal to private schools through various means; for example, Georgia encouraged private schools to enact their own Seal of Biliteracy and shared resources to support those efforts, while Maryland drafted a policy amendment to allow private schools to participate. Other states embraced the nebulous wording of policies to extend the award to private school contexts. Indiana and Kansas awarded the Seal to students at any school accredited by the state, which opened the opportunity to private schools. Minnesota and Nevada legislation did not specify public schools, which prompted deliberation among stakeholders to extend the Seal more broadly. Moving beyond the assumption that language education occurs in formal school settings, Maryland and New Jersey specifically highlighted the role of community-based language education efforts in promoting heritage languages.

Contexts also varied by languages targeted and prioritized during implementation. With the exception of Hawai' $i$, states awarded the Seal of Biliteracy most often in Spanish, reflecting the prevalence of Spanish among world and heritage language learners nationwide. But states varied significantly in the other languages formally recognized by the Seal of Biliteracy, which involved having available assessments to evaluate students' proficiency. In states that designed the policy with the broad focus on bilingualism for all students or attached the initiative directly to world language education, languages remained limited to those commonly taught in school 
settings (e.g., Spanish, French). In states that initiated the policy with the goal to maintain heritage languages, a more diverse array of languages emerged in the implementation to match the linguistic backgrounds of students, including immigrant and indigenous languages, as well as others like American Sign Language and Latin. Stakeholders in these states engaged in ongoing efforts to seek out both human and material resources to design assessments and instructional opportunities that aligned to linguistic backgrounds of students, such as Somali, Hmong, and Dakota in Minnesota, and Swahili and Cebuano in New Jersey.

Each participating state had a nuanced policy journey, reflecting various policy pathways influenced by diverse stakeholder voices and choices. Nonetheless, D.C. and Hawai ‘i emerged as unique locales that demonstrated how various facets of the sociocultural context shaped the policy journey. These contexts are explored below.

\section{District of Columbia.}

In our nation's capital on the eastern seaboard, approximately 583,000 people live in a 68 square-mile area, with 16\% speaking one of 79 languages other than English (U.S. Census, 2015). Unique from other contexts whose journeys began with state legislation, D.C.'s Seal of Biliteracy began within the D.C. Public Schools (DCPS). After unsuccessfully reaching out to the state board of education, one district leader moved ahead to enact the language policy at the district level in 2014, becoming the $9^{\text {th }}$ locale to offer the Seal of Biliteracy. She explained,

When I proposed it to our state board, there was no response so we moved forward with a district-level award... I wrote a proposal to bring the Seal to DCPS and presented it to our chiefs. With initial tentative approval, we held a community forum inviting representatives from various embassies, language organizations, and education organizations to help develop the criteria for the Seal and to get feedback on the process. 
Based on feedback from various stakeholders, the DCPS Seal of Biliteracy incorporated unique and rigorous requirements including cultural competencies in addition to language proficiency.

District leaders have worked to implement and expand the Seal of Biliteracy across the city's high schools, while recognizing and seeking to respond to particular challenges. Initial efforts resulted in the Seal being awarded to primarily White and Latino students from two highperforming high schools, despite White and Latino students comprising only $31 \%$ of the district. With almost $65 \%$ of the D.C. student population identifying as Black, the district conducted targeted outreach in high schools with predominantly African American students to ensure equal access by racial demographics across the metropolitan area. Leaders also considered the role of heritage languages with the goal to "explicitly encourage students who may not meet the [award] criteria but who are truly bilingual and biliterate." With the support of language educators, district leaders developed "case-by-case protocols" to encourage students to pursue the award in "outlier" languages other than Spanish, including those spoken by the large population of African immigrants. One particular language of focus is Amharic, the fourth most common language in the D.C. area after English, Spanish, and French. Based on these ongoing efforts in DCPS, the state board has recently inquired about expanding the Seal of Biliteracy to public charter and private schools within the metropolitan area.

\section{Hawai'i}

Situated off the U.S. continent in the Pacific Ocean, the island state of Hawai' $i$ is located 2,390 miles from California and 3,850 miles from Japan. This exclusive location brings a diverse array of languages to the American repertoire, including the indigenous language of 'Ōlelo Hawai'i (i.e., Hawaiian) and various Asian, Pacific Islander, and other non-English languages used by $25 \%$ of the state's population (U.S. Census, 2015). Hawai' $i$ became the $14^{\text {th }}$ context in 
the United States to pass Seal of Biliteracy policy in 2015. Relatively small and remote, Hawai ' $i$ is unique in that it has one school district and one Board of Education that spans the entire state. In this way, all public high schools participate in the award program. Reflecting "parallel movements" to promote multilingualism and flesh out the state's EL policy, the Seal of Biliteracy emerged with the goal to "recognize the assets and strengths of EL students, recognizing and maintaining languages... with more opportunities and diversity in language programs." While the Hawaiian language is a predominant focus of bilingual education in the state, stakeholders wanted to value and embrace the other 95 languages spoken by students and families (U.S. Census, 2015).

State administrators and community stakeholders have collaborated to design protocols and assessments targeting the "low-hanging fruit," specifically the commonly taught languages of Japanese, Chinese, and French. They have continued working on assessments for the Hawaiian language and the home languages of the majority of ELs, including Filipino (e.g., Tagalog, Ilocano) and Micronesian (e.g., Marshallese, Chuukese) languages. Unlike other states involved with the Seal of Biliteracy, Hawai'i does not require English as one of the two languages to indicate biliteracy. Since both Hawaiian and English are official state languages, students can demonstrate proficiency in either language, in addition to another world or heritage language. One state administrator explained, "The way it [the policy] is written, a person who speaks Hawaiian... that could be their anchor language. So they could have Hawaiian and Japanese [to receive the Seal of Biliteracy], it doesn't just have to be English and another [language]." State administrators collaborated with faculty in the modern language departments at the University of Hawai'i (i.e., East Indian languages, Indo-Pacific languages, languages of Europe and the Americas) to develop assessments targeting the diverse linguistic populations in 
the state, as well as to ensure that the awards on students' high school transcripts transfer into college credit.

\section{Discussion}

In this study, we probed how policy work has unfolded in attempt to promote K-12 students' biliteracy. Approached broadly by considering how states have enacted the Seal of Biliteracy across the nation, this study reveals the bottom-up nature of these policy journeys. In contrast to top-down policy efforts where macro-level stakeholders and jurisdictions attempt to mandate programs and practices, the Seal of Biliteracy represents a grassroots educational movement that has emerged from within local communities and states in attempt to challenge monolingual ideologies in American society (Crawford, 2000; Wiley \& Lukes, 1996). This study adds to the extant literature in its focus on the complex storylines of bottom-up policies, a novel concept in American educational reform (Mehta, 2013). As evidenced in the collective and individual narratives of states' policy journeys, the grassroots nature of the Seal of Biliteracy movement prompted the action, agency, and advocacy of various stakeholders as the plot unfolded across the stages of initiation, design, and implementation.

Despite the power of these grassroots efforts, policy journeys also involved combatting various challenges. As illustrated in this study, many challenges are solvable by enlisting the support of interested stakeholders with their concomitant human and material resources. Previous work in the field has confirmed the multifaceted layers and actors involved in language policy and planning (Author, 2016; Hornberger \& Johnson, 2007; Ricento \& Hornberger, 1997). The present study illustrated how diverse voices and choices came together to influence policy journeys over time, including the interconnected processes of policy initiation, design, and implementation (Honig, 2006; Levinson \& Sutton, 2001). Specifically focused on the nascent 
language policy of the Seal of Biliteracy, findings revealed the dynamic shaping of states' policy journeys as connected to the perspectives and expertise of various individuals and groups. We also found a mutual constitution between policies and people; in other words, just as people influenced the policies, the policies regulated the people involved (Honig, 2016; Rogoff, 2003). For example, Minnesota's inclusion of universities in the formal legislation prompted professors and other university stakeholders to engage with the K-12 language policy, which then shaped its implementation in practice across the state. Overall, this study suggests that the involvement of multiple stakeholders from diverse groups can enrich and positively shape policy journeys, making the policy outcomes - in this case, the Seal of Biliteracy - accessible to students in a diverse array of classrooms, schools, and districts.

While states can learn from one another, the notion of flexibility is integral to grassroots policy efforts. Findings from this study indicate that unique contexts must drive decision-making to promote successful enactment of policy in practice. Across policy journeys, stakeholders made decisions to push forward efforts within particular contexts: D.C. initiated efforts at the district level after inaction by the state board, Georgia framed the policy around elite bilingualism to get through a conservative legislature, Hawai'i forged university partnerships to design assessments for less commonly taught languages, and Illinois provided flexibility for implementation within vastly different districts. These findings align with research on educational efforts to promote multilingualism in international contexts, where language policy and planning respond to the needs of local communities (Chimbutane, 2011; Davis, 1994; Hornberger, 1988, 2002; Wright \& Boun, 2016). Significance of these findings center on K-12 educational policy in the United States, particularly at a time when states are being allowed more flexibility from the federal government with the recent shift to the Every Student Succeeds Act (ESSA). As states are 
afforded more control in educational decision-making, both with regard to language education and beyond, stakeholders must recognize and embrace the opportunity to respond to the unique needs and nuanced contexts within and across their state.

These dynamic policy contexts include increasingly diverse populations of students speaking over 350 languages (U.S. Census, 2015). Nonetheless, most Seal of Biliteracy initiatives have focused broadly on the biliteracy of all students, with the policy discourse either implicitly or explicitly prioritizing the elite bilingualism of English-dominant students learning world languages. Of the 18 states and D.C. that participated in our study, only five prioritized ELs, linguistically diverse students, or heritage language maintenance when stating the policy's purpose in the legislation or code. At the time of data collection, only three states collected and disaggregated data to be able to share the number of bilingual heritage learners receiving the Seal of Biliteracy. Additionally, findings from this study indicated on-the-ground challenges to policy implementation that influenced linguistically diverse students, such as securing or designing assessments for less common languages without funding. Taken together, these findings signal that despite good intentions to promote students' multilingual abilities, Seal of Biliteracy policies could potentially serve to perpetuate hierarchies between English-dominant world language learners and bilingual heritage learners.

\section{Implications}

Grounded in the findings of this study, we can glean implications and recommendations for future work to advance the Seal of Biliteracy policy. In states that have already enacted the Seal of Biliteracy, stakeholders can expand policy work in ways that directly support local educators in districts, schools, and classrooms, working toward the goal of promoting bilingualism and biliteracy with as many students as possible, including an explicit lens on 
bilingual heritage learners from diverse language backgrounds. In states that are newly initiating the Seal of Biliteracy, stakeholders should seek resources, perspectives, and sources of expertise (e.g., teachers, university faculty, business leaders, language education organizations), while staying true to the unique needs of students, schools, and communities in the region. In states that have not yet enacted the language policy, interested individuals and organizations should feel empowered to embark upon the journey, knowing that they could be the spark to initiate a movement to fuel multilingualism for hundreds of thousands of students. Finally, to promote collaboration around these efforts across states where stakeholders learn from one another's journeys and experiences, national organizations for language education (e.g., ACTFL, NABE) must work together and continue to serve as hubs for communication, resources, and ongoing support.

This study explored the Seal of Biliteracy with a nationwide lens on states' policy enactment. Aiming to capture the broad scope of the work across the United States, the current research did not probe the actions and interactions of local policy actors in schools and districts. To capture and understand the implementation and implications of policy in practice, future research should include multiple stakeholders in local contexts engaged in the daily work of developing students' biliteracy (McCarty, 2011; Menken \& García, 2010). Due to limited research on the Seal of Biliteracy, there is no shortage of opportunities for researchers and educators to investigate various facets of the policy in practice, including storied experiences and resultant outcomes of all actors involved (e.g., students, parents, teachers, leaders) both within and across contexts in the United States. Various efforts are emerging in local contexts across the country to stimulate students' biliteracy development to further these language policy efforts, such as building K-12 dual-language programs, revamping world language curricula, and 
partnering with community language schools and settings. By investigating and understanding the nuanced efforts and outcomes related to the Seal of Biliteracy, researchers and other stakeholders can grapple with how to tackle other contemporary issues in education with grassroots policy efforts that push back against the status quo in American society. 


\section{References}

ACTFL, National Association for Bilingual Education, National Council of State Supervisors for Languages, \&Teachers of English to Speakers of Other Languages International Association. (2015). Guidelines for implementing the Seal of Biliteracy. Joint report. Retrieved March 21, 2018, from http://www.actfl.org/sites/default/files/pdfs/SealofBiliteracyGuidelines_0.pdf.

Author. (2016).

Authors. (2017).

Authors. (in press).

Bhatia, T. K., \& Ritchie, W. C. (2013). Bilingualism and multilingualismin South Asia. In T. K. Bhatia \& W. C. Ritchie (Eds.), The handbook of bilingualism and multilingualism: Second edition. Hoboken, NJ: Blackwell.

Bialysok, E. (2007). Cognitive effects of bilingualism: How linguistic experience leads to cognitive change. International Journal of Bilingual Education and Bilingualism, 10, 210-223.

Bialystok, E., Craik, F. I. M., \& Freedman, M. (2007). Bilingualism as a protection against the onset of symptoms of dementia. Neuropsychologia, 45, 459-464.

Burnet, M. M. (2017). Signed, sealed, delivered: District-level adoption of the Washington State Seal of Biliteracy. University of Washington, Washington.

Byram, M. (1997). Teaching and assessing intercultural communicative competence. Clevendon, UK: Multilingual Matters.

Callahan, R., \& Gándara, P. (2014). The bilingual advantage: Langauge, literacy, and the US labor market. Bristol, UK: Multilingual Matters. 
Castro-Santana, A. C. (2014). Herencia y llegado: Validating the linguistic strengths of English language learners via the LAUSD Seal of Biliteracy. Unpublished dissertation for California State University.

Chimbutane, F. (2011). Rethinking bilingual education in postcolonial contexts. Bristol, UK: Multilingual Matters.

Clandinin, D. J., \& Connelly, F. M. (2000). Narrative inquiry: Experience and story in qualitative research. Hoboken, NJ: Jossey-Bass.

Commission of European Communities. (2003). Promoting language learning and linguistic diversity: An action plan 2004-2006. Retrieved on April 12, 2017 from www.eu.int/comm/education/doc/official/keydoc/actlang/act_lang_en.pdf

Connelly, F. M., \& Clandinin, D. J. (1990). Stories of experience and narrative inquiry. Educational Researcher, 19, 2-14.

Crawford, J. (2000). At war with diversity: US language policy in an age of anxiety. Tonawanda, NY: Multilingual Matters.

Cummins, J. (2000). Language, power, and pedagogy: Bilingual children in the crossfire. Buffalo, NY: Multilingual Matters.

Davis, K. A. (1994). Language planning multilingual contexts: Policies, communities, and schools in Luxembourg. Philadelphia, PA: John Benjamins.

Dawson, D., \& Sandrock, P. (2017). Conference presentation for the American Council on the Teaching of Foreign Languages.

DeLeon, T. M. (2014). The new ecology of biliteracy in California: An exploratory study of early implementation of the State Seal of Biliteracy. Unpublished dissertation for Loyola Marymount University. 
Digest for Education Statistics. (2015). English language learner students enrolled in public elementary and secondary schools. Retrieved on April 12, 2017 from https://nces.ed.gov/programs/digest/d15/tables/dt15_204.27.asp

Erickson, F. (1986). Qualitative methods in research on teaching. In M. Wittrock (Ed.), Handbook of research on teaching ( $3^{\text {rd }}$ edition, pp. 119-161). New York: MacMillan.

Gross, N. (2016). Dual-language programs on the rise across the US. Washington, DC: Education Writers Association. Retrieved on April 12, 2017 from http://www.ewa.org/blog-latino-ed-beat/dual-language-programs-rise-across-us

Honig, M. I. (2006). Complexity and policy implementation: Challenges and opportunities for the field. In M. I. Honig (Ed.), New directions in education policy implementation: Confronting complexity (pp. 1-24). Albany, NY: State of New York Press.

Hornberger, N. H., \& Johnson, D. C. (2007). Slicing the onion ethnographically: Layers and spaces in multilingual language education policy and practice. TESOL Quarterly, 41, 509-532.

Hornberger, N. H. (2003). Continua of biliteracy: An ecological framework for educational policy, research, and practice in multilingual settings. Clevendon, UK: Multilingual Matters.

Hornberger, N. H. (1988). Bilingual education and language maintenance: A southern Peruvian Quechua case. Berlin: Mouton de Gruyter.

House Bill 879. (2016). Georgia's Seal of Biliteracy. Retrieved on April 12, 2017 from http://www.gadoe.org/Curriculum-Instruction-and-Assessment/Curriculum-andInstruction/Pages/Georgia\%27s-Seal-of-Biliteracy.aspx 
Lee, J. S., \& Wright, W. E. (2017). The rediscovery of heritage and community language education in the United States. Review of Research in Education, 38, 137-165.

Levinson, B. A. U., \& Sutton, M. (2001). Introduction: Policy as/in practice - A sociocultural approach to the study of educational policy. In M. Sutton (Ed.), Policy as practice: Toward a comparative sociocultural analysis of educational policy (pp. 1-22). Westport, CT: Ablex.

McCarty, T. (2011). Ethnography and language policy. New York: Routledge.

McLeay, H. (2003). The relationship between bilingualism and the performance of spatial tasks. International Journal of Bilingual Education and Bilingualism, 6, 423-438.

Mehta, J. (2013). The allure of order: High hopes, dashed expectations, and the troubled quest to remake American schooling. New York: Oxford.

Menken, K., \& García, O. (2010). Introduction. In K. Menken \& O. García (Eds.), Negotiating language policies in schools: Educators as policymakers (pp. 1-10). New York: Routledge.

Multilingual Chicago. (2017). About us. Retrieved September 13, 2017 from http://multilingualchicago.org/About

Ng, E. (2015). Bilingualism, biliteracy and cognitive effects: A review paper. University of Sydney Papers in TESOL, 10, 93-128.

Oppendaker, R. (2006). Advantages and disadvantages of four interview techniques in qualitative research. Qualitative Social Research, 7, 4-11.

Ricento, T. K., \& Hornberger, N. H. (1996). Unpeeling the onion: Language planning and policy and the ELT professional. TESOL Quarterly, 30, 401-427. 
Rogoff, B. (2003). The cultural nature of human development. New York: Oxford University Press.

Seal of Biliteracy. (2016). Seal of biliteracy. Retrieved January 10, 2017 from www.sealofbiliteracy.org

Seidman, I. (2005). Interviewing as qualitative research: A guide for researchers in education and the social sciences, $3^{\text {rd }}$ edition. New York: Teachers College Press.

Suárez-Orozco, M. (2001). Globalization, immigration, and education: The research agenda. Harvard Educational Review, 71, 345-366.

Smith, T. W., Marsden, P. V., \& Hout, M. (2011). General social survey, 1972-2010 cumulative file ICPSR31521-v1. Chicago IL: National Opinion Research Center.

United States Census. (2015). Retrieved on April 14, 2017 from https://www.census.gov/newsroom/press-releases/2015/cb15-185.html

Wiley, T. G., \& García, O. (2016). Language policy and planning in language education: Legacies, consequences, and possibilities. Modern Language Journal, 100, 48-63.

Wiley, T. G., \& Lukes, M. (1996). English-only and standard English ideologies in the US. TESOL Quarterly, 30, 511-535.

Wright, W. E., \& Boun, S. (2016). The development and expansion of multilingual education in Cambodia: An application of Ruiz's orientations in language planning. The Bilingual Review, 33, 1-17.

Zelasko, N., \& Antunez, B. (2000). If your child learns in two languages. Washington, DC: National Clearinghouse for Bilingual Education.

Zsiga, E., Boyer, O., \& Kramer, R. (Eds.) (2014). Languages in Africa: Multilingualism, language policy, and education. Washington, DC: Georgetown University Press. 
Figure 1: Timeline of States' Legislation on the Seal of Biliteracy

\begin{tabular}{|c|c|c|c|c|c|c|}
\hline 2011 & 2013 & 2014 & 2015 & 2016 & 2017 & 2018 \\
\hline California & $\begin{array}{c}\text { Texas } \\
\text { New York } \\
\text { Illinois }\end{array}$ & $\begin{array}{c}\text { New Mexico } \\
\text { Washington } \\
\text { Louisiana } \\
\text { Minnesota } \\
\text { District of } \\
\text { Columbia }\end{array}$ & $\begin{array}{c}\text { North Carolina } \\
\text { Virginia } \\
\text { Indiana } \\
\text { Nevada } \\
\text { Hawai`i } \\
\text { Wisconsin } \\
\text { Utah }\end{array}$ & $\begin{array}{c}\text { New Jersey } \\
\text { Florida } \\
\text { Oregon } \\
\text { Maryland } \\
\text { Georgia } \\
\text { Arizona } \\
\text { Kansas } \\
\text { Rhode Island }\end{array}$ & $\begin{array}{c}\text { Ohio } \\
\text { Colorado } \\
\text { Connecticut } \\
\text { Delaware } \\
\text { Missouri } \\
\text { Massachusetts }\end{array}$ & $\begin{array}{c}\text { Michigan } \\
\text { Tennessee } \\
\text { Iowa } \\
\text { Arkansas }\end{array}$ \\
\hline
\end{tabular}


Figure 2: Researching Policy in Practice (Honig, 2006)

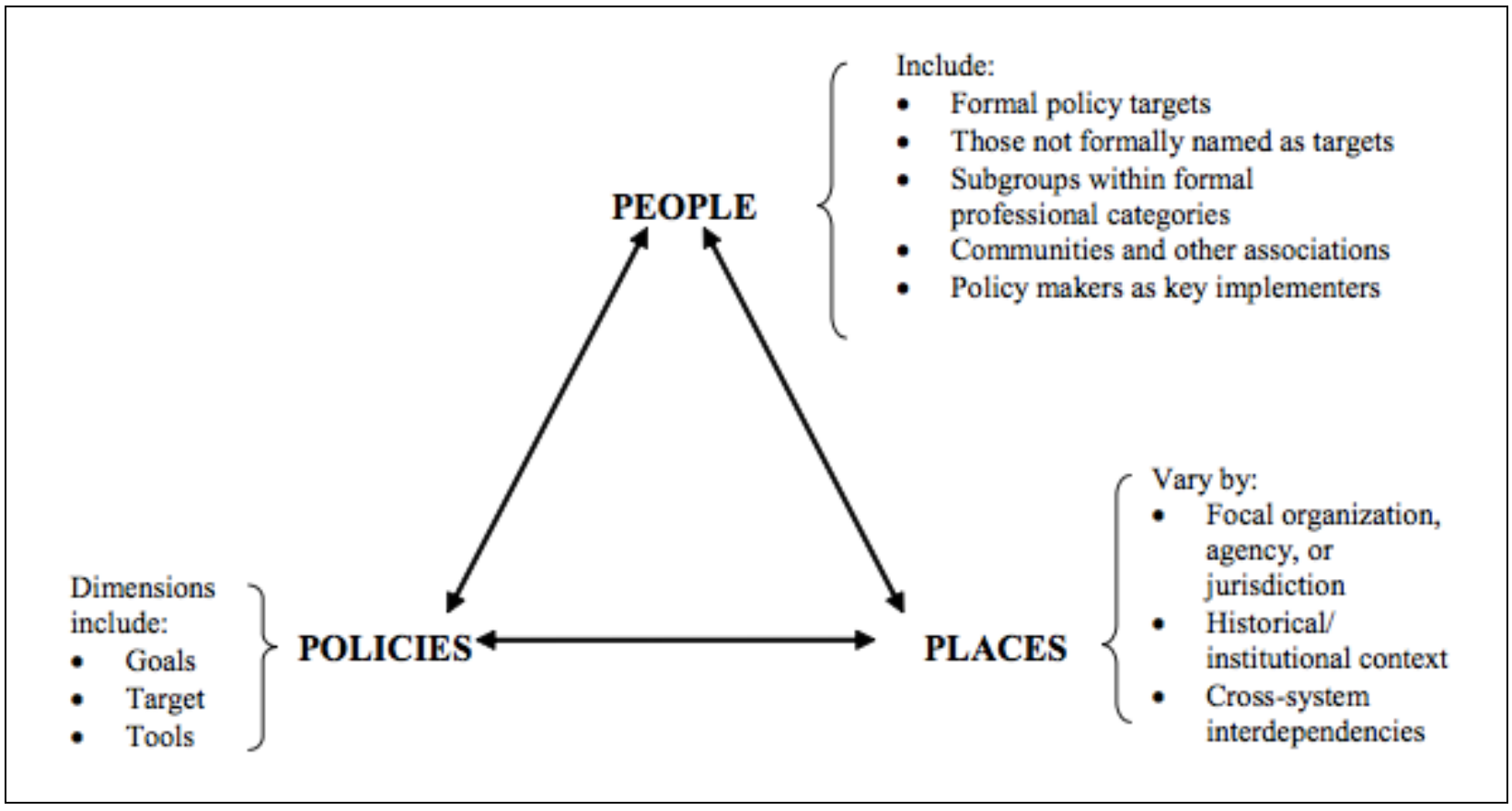


Table 1: Coding Scheme

\begin{tabular}{|c|c|c|}
\hline Policies & People & Places \\
\hline $\begin{array}{l}\text { Goals/targets: } \\
\begin{aligned} \text { - } & \text { All learners } \\
\text { - } & \text { Heritage learners }\end{aligned}\end{array}$ & $\begin{array}{l}\text { Educational professionals: } \\
\text { - Teachers } \\
\text { - Local administrators } \\
\text { - State administrators }\end{array}$ & $\begin{array}{l}\text { Focal jurisdiction: } \\
\begin{aligned} \text { - } & \text { State-level } \\
\text { - } & \text { District-level }\end{aligned}\end{array}$ \\
\hline $\begin{array}{l}\text { Policy processes: } \\
\begin{array}{l}\text { - Initiation } \\
\text { - Design } \\
\text { - Implementation } \\
\text { - } \text { Opposition } \\
\end{array}\end{array}$ & $\begin{array}{l}\text { Communities \& associations: } \\
\text { - Education interests } \\
\text { - Language interests } \\
\text { - Business interests }\end{array}$ & $\begin{array}{l}\text { Contextual variables: } \\
\begin{array}{l}\text { - Linguistic diversity } \\
\text { - Learning contexts } \\
\text { - Funding }\end{array}\end{array}$ \\
\hline $\begin{array}{l}\text { Policy-related tools: } \\
\text { - Assessments } \\
\text { - Award levels }\end{array}$ & Legislators \& policy makers & $\begin{array}{l}\text { Cross-system interdependencies } \\
\text { - State-to-state } \\
\text { - State-district }\end{array}$ \\
\hline
\end{tabular}




\section{Prioritizing Multilingualism in U.S. Schools: States' Policy Journeys to Enact the Seal of Biliteracy}

\section{Amy J. Heineke, Ph.D.}

Loyola University Chicago

School of Education

Associate Professor of Education

Bilingual/Bicultural Education

820 North Michigan Avenue

Lewis Towers, $11^{\text {th }}$ Floor

Chicago, Illinois 60611

aheineke@luc.edu

\section{Kristin J. Davin, Ph.D.}

University of North Carolina at Charlotte

Cato College of Education

Assistant Professor of Education

Foreign Language Education

9201 University City Blvd

Charlotte, North Carolina 28223

kdavin@uncc.edu 